\title{
Hiring Strategies for Small Business Owner to Recruit Veterans (A Multiple Case Study)
}

\author{
Jamillah D. Stackhouse \\ U.S. Army, Atlanta, GA, USA \\ Email: jamill.johnson34@gmail.com
}

How to cite this paper: Stackhouse, J. D. (2020). Hiring Strategies for Small Business Owner to Recruit Veterans (A Multiple Case Study). Open Journal of Business and Management, 8, 1508-1535.

https://doi.org/10.4236/ojbm.2020.84096

Received: May 23, 2020

Accepted: July 6, 2020

Published: July 9, 2020

Copyright $\odot 2020$ by author(s) and Scientific Research Publishing Inc. This work is licensed under the Creative Commons Attribution International License (CC BY 4.0).

http://creativecommons.org/licenses/by/4.0/

(c) (i) Open Access

\begin{abstract}
Grounded in recruitment theory, the purpose of this qualitative multiple case study was to explore the strategies used by leaders of small businesses to recruit, hire, and retain qualified veterans. The targeted population consisted of three leaders of small businesses in the southeastern Virginia area who have used successful strategies to recruit, hire, and retain veterans. Data were collected using semistructured interviews and document review. Data were analyzed using thematic analysis, and 4 themes emerged: social media advertisement, local networking with military facilities, workshop and job description, and resume review and effective communication. The finding of this study included that participants advertised job vacancies through social media, military post advertisements, human resource boards, and small business administration. Each participant agreed that the labor force hiring process consists of competition with other civilian entities. The implications for positive social change in organizations include influencing owners of small businesses with knowledge of potential growth in local economies and supporting military veterans.
\end{abstract}

\section{Keywords}

Candidates, Military Transition, Military Veteran, Skilled Veteran, Small

Business, Transition Assistant Program

\section{Introduction and Background}

Military veterans have vital skills that can incorporate integrity, experience, agility, values, and ethics to enhance the success rate of small businesses. Military veterans hold skillful jobs in human resources, medical personnel, engineering, law enforcement, logistics, and aviation that bring a wealth of experience to civilian businesses. In 2017, an estimated 370,000 skilled retired military personnel 
were unemployed, an average of $59 \%$ between the ages of 25 and 54 (U.S. Department of Labor, 2017). Thousands of veterans who depart the armed forces fail to find gainful employment (Faurer, Rogers-Brodersen, \& Bailie, 2014). An average of 300,000 skilled veterans quit the armed forces annually (Faurer et al., 2014). The military experience provides individuals with professional skills that improve and develop leadership traits (Beauchesne \& O'Hair, 2013). Military veterans have experience in leadership and management skills, adaptability techniques, resiliency, and strategies that can increase organizations' profits; these skills are instrumental to the success of a business. Military veterans hold skilled jobs in human resources, medical personnel, and engineering (Beauchesne \& O’Hair, 2013).

Small business leaders routinely fail to attract highly qualified employees among the population of military veterans, placing their organizations at a competitive disadvantage (Lee, Idris, \& Tuckey, 2019). Between 2014 and 2016, almost $80 \%$ of veterans who exited the military had not secured employment in the civilian sector (Zogas, 2017). Thousands of businesses open each year in the United States that account for $64 \%$ of new jobs in small businesses (U.S. Small Business Administration (SBA), 2014). Military veterans face a rocky transition to the civilian world because managers lack knowledge of veterans' qualifications (Brown \& Lent, 2013). Many veterans face hardship after exiting the military service and find it difficult to find employment outside of the military (Harrell \& Berglass, 2012). Hiring managers can employ experienced veterans to fill vacant positions, but they tend to overlook veterans between the ages of 25 and 50 as potential candidates (Beauchesne \& O'Hair, 2013). Overlooking this pool of employees could potentially place organizations at a competitive disadvantage ( $\mathrm{Fa}$ berman \& Foster, 2013).

\section{Problem Statement}

Small business leaders routinely fail to attract highly qualified employees from the population of military veterans, placing their organizations at a competitive disadvantage (Lee et al., 2019). Even with additional funds from the federal government allocated to assist companies in hiring veterans, the U.S. Census Bureau reports an unemployment rate of $5.1 \%$ among veterans in the state of Virginia (U.S. Census Bureau, 2015). This demographic consists of qualified veterans with a variety of skills and a workforce that includes skilled veterans, who could address adverse trends in an organization's productivity and profits. The general business problem is that leaders of small businesses lack strategies for recruiting, hiring, and retaining veterans, which can result in profit reductions or losses. The specific business problem is that some business leaders in small businesses lack strategies to recruit, hire, and retain qualified military veterans.

\section{Purpose Statement}

The purpose of this qualitative multiple case study was to explore the strategies 
used by leaders of small businesses to recruit, hire, and retain qualified veterans. The targeted population consisted of three leaders of small businesses in the southeastern Virginia area who have used successful strategies to recruit, hire, and retain veterans. The leaders of the selected small businesses have indicated their devotion to increasing workforce capability, production capability, and overall performance. The findings from this study may affect positive social change in organizations by influencing owners of small businesses with knowledge of successful processes for recruiting, hiring, and retaining veterans. Small business leaders may catalyze growth in local economies, increase prosperity, and increase the opportunity to support veteran military veteran.

\section{Research Question}

The Central Research Question guiding this study was what strategies do small business leaders use to recruit, hire, and retain military veterans? Data derived from open-ended semistructured questions, archived data, and observations.

\section{Assumptions, Limitations, and Delimitations}

Assumptions are facts assumed as true without evidence (Flannery, 2016). Lewin et al. (2015) described limitations as restrictions that limit the research in a study and could alter validity in research. A researcher cannot control limitations. Delimitations narrow researchers' scope of research. Delimitations aid researchers in identifying the restrictions and boundaries of the research (Yin, 2017).

I assumed that the participants in this study were appropriate for exploring strategies used by small business owners to employ veterans. I assumed that all participants would be honest and thorough in their responses. I also assumed that participants had enough knowledge to provide detailed answers to the research question. In this study, I assumed that the sample size was enough to answer the research question.

The limitations of this study included time constraints. Interviewing participants in a short amount of time is difficult. Therefore, interviews were scheduled during the evening hours and weekends. The results of the study are limited by the honesty and thoroughness of the participants' responses. The participants' availability to respond to interview questions in enough detail did not limit the results of the study. The availability of documentation to support the participants' interview responses did not limit the results of the study. My ability to recruit enough participants to allow for data saturation did not limit the results of the study. Finally, participants' knowledge of the subject did not limit the results.

The delimitation boundaries of this study limited the participants to small business owners who have successfully hired military veterans in the southeastern Virginia area. An additional delimitation was limiting the intended scope of this study to three small businesses in the state of Virginia that focus on recruiting military veterans as potential recruits and employees. This study included businesses with fewer than 500 employees, which are not considered medium or 
large companies. Another delimitation was the location of each organization; the three businesses were located throughout the state of Virginia.

\section{Significance of the Study}

In 2016, the Department of Defense allocated a budget that exceeded $\$ 8.7$ billion to train military personnel required skills needed to find gainful employment (U.S. Department of Defense, 2016). Small business owners need skilled and qualified employees to ensure high quality, performance, and production within the firm to maximize output and profits. The significance of this study may show useful for small business owners to increase recruiting strategies and capitalize on the best recruitment practices, which may reduce veterans' unemployment and increase employment among this population.

\section{Contributions to Business Practice}

This study may be of value to the practice of business because the findings and recommendations may become a tool for creating strategic, operational plans for hiring qualified veterans. The results of this study may provide business leaders lacking recruitment skills with the developmental strategies to improve recruitment strategies in organizations. Business leaders seek to employ knowledgeable workers who may maximize production, profits, and sustainability (Blatter, Muehlemann, \& Schenker, 2012). Managers strive to capitalize on identification and recruitment methods of qualified veterans as well as their retention, allowing business leaders the opportunity to capitalize on investments, which may increase the overall knowledge in the business community and profits. The specialized skills of veterans, for example, management/leadership, administration, and human resources may generate or increase revenue in organizations by significantly reducing recruitment and training expenses. If small business leaders understand effective recruitment strategies and use that knowledge when recruiting, identifying, and retaining military veterans, they may increase the organization's overall performance level, which could potentially contribute to higher profits and sustainability.

\section{Implementations for Social Change}

The implications for potential contribution to positive social change may include decreasing the unemployment rate of veterans in the United States. Effective recruitment and retention strategies in organizations might contribute to the employment rate in southeastern Virginia and the workforce and community. The improvement of business practice could improve wages and living conditions, which may increase the local community's economy.

\section{A Review of the Academic Literature}

\section{Recruitment Theory}

Dunnette introduced the recruitment theory in 1976. The constructs within the recruitment theory include three groups: 1) finding skilled workers, 2) identifying individuals with the potential skills, and 3) employing the best candidates for the job (Ekwoaba, Ikeije, \& Ufoma, 2015). Ekwoaba et al. (2015) described 
the recruitment phase as vital to organizations when managed appropriately. During the recruitment stage, organizational leaders know that potentially qualified candidates offer values and perspectives to the life of an organization, therefore providing skills to increase organization profits (Ekwoaba et al., 2015). Dunnette (1976) used the recruitment theory to identify structure within recruitment that affects employees' behaviors and determines the right combination of recruitment activities. The best way to ensure an organization is successful is by seeking quality applicants who are suitable and possess the talent and knowledge to succeed in the organization (Ekwoaba et al., 2015). Ekwoaba et al. (2015), Chungyalpa and Karishma (2016) posited that if organizational leaders want to hire the most qualified candidates, they must expand their recruitment focus. Therefore they should include veterans who are not actively seeking new employment, and open to the possibility of obtaining new employment. Adding support to Chungyalpa and Karishma, Ekwoaba et al. described the recruitment stage as an introduction to potential employees and making them aware of open positions within the organization. Therefore, I selected the recruitment theory as my conceptual framework.

A professional environment sets the stage for candidates, regardless of their successor's failures in the organization (Ekwoaba et al., 2015). Based on the constructs of recruitment theory, understanding recruitment changes and needs while embracing the strengths of qualified veterans may increase overall revenue and assets of small businesses (Farndale, Biron, Briscoe, \& Raghuram, 2015). The recruitment theory could help highlight gaps and developmental areas and provide business leaders with knowledge of qualified veterans seeking employment (Boudreau \& Rynes, 1985). Qualified employees who have experience can produce a favorable outcome in an organization, in contrast a lack of experience could have a damaging result (Ekwoaba et al., 2015). According to Ekwoaba et al. (2015), business owners must have knowledge in recruitment to understand what talent is necessary to have a successful business that includes internal and external recruitment.

\section{Small Business Management}

Small business managers need practical and robust leadership skills to have a successful business. Hyytinen, Pajarinen, and Rouvinen (2015) posited that small business managers hold a variety of positions in all organizations, causing concerns about profits and sustainability. Organizations with less than $100 \mathrm{em}$ ployees have a high employment rate compared to organizations with over 500 employees (U.S. Small Business Association (SBA), 2018). Business leaders must invest in neighboring connections with employees to implement strategies to have a productive outcome with profits.

Small business in the United States plays an integral part in today's economy. According to the United States Small Business Administration (SBA, 2017), approximately $61.8 \%$ of new jobs were small business owners that generated positive revenues and remained stable for 24 years. Jaouen and Lasch (2015) posited 
that the views held by owners have significant effects on the strategies and subsequent development of small businesses. A total of $79.9 \%$ of small businesses established in 2015 survived and maintained a solid structure for at least a year; half of the small businesses survived five-year (SBA, 2017). For example, in 2014, there were 403,902 small businesses started, of that population 391,553 of the businesses closed within a year (SBA, 2017), which is a remaining 12,349 small businesses that survived. High technology firms' account for $98 \%$ of small businesses in the U.S., and $46 \%$ consist of computer systems design and servicing business. The SBA (2017) indicated that military veterans owned and operated 2.5 million small businesses, which accounted for $9.1 \%$ of the U.S. firms. Small businesses continue to show a solid foundation in corporate America and create jobs in America. According to Hyytinen et al. (2015), one reason new small businesses thrive is the ability of the owner and managers to maintain flexibility within their policies and procedures. In 2011,30\% of veterans owned small businesses and provided the highest jobs in the construction field, scientific, and technical services department (SBA, 2017). The following states with the highest percentage of veteran-owned businesses were: California, Texas, Florida, New York, and Pennsylvania (SBA, 2017). Meanwhile, South Carolina, New Hampshire, Virginia, Alaska, and Mississippi had the highest percentage of veteran-owned small businesses (SBA, 2017).

In 2017, the GDP in the U.S. increased by 3.4\% (SBA, 2017). There was a GDP increase averaging 1.5\% between 2016 and 2017 (SBA, 2017). Small business employment played a significant role in the growth of the economy. Small businesses alone created over 1.9 million jobs during 2015; this number accounts for employing 1.1 million jobs in one year (SBA, 2017). Therefore, small businesses have a more significant impact on U.S. employment compared to fortune 500 companies. According to the SBA (2017), those small businesses that obtained the lowest return on investment were larger firms with more than 100 employees but not greater than 500 .

Small business owners hold the responsibility of ensuring all daily functions in each department work efficiently. Hyytinen et al. (2015) noted that small business owners seek skilled recruits to occupy vacant positions. Small business owners need to set the right environment for the organization (Ben-Hur, Jaworski, \& Gray, 2015). In a small business, owners must be marketable to compete with Fortune 500 companies (Hyytinen et al., 2015). To remain competitive, small business owners must employ experienced workers; however, the cost of goods hinders revenues and success. Small business owners must train and develop recruits to effectively communicate with stakeholders in order to optimize and implement policies and procedures (Gutiérrez-Broncano, Jiménez-Estévez, \& del Carmen Zabala-Baños, 2017). A few concerns that affect small business owners are 1) a limited number of employees available to production output, 2) lack of experienced worker, and 3) long work hours (Kube, Maréchal, \& Puppe, 2013). 
Small business managers have a significant responsibility to make corrections in the workforce. To boost motivation, small business managers use the decision-making process to identify strong leadership, exceptional performance, and responsibilities in the workplace (Bolman \& Deal, 2015). The amount of time invested in the decision-making process is vital, and business owners who employ military veterans observe increased productivity and active production with veterans. One of the most significant tasks for small business managers in the decision-making process is finding the right fit for the organization (Bolman \& Deal, 2015; Dubrin, 2015). Often, decisions are instantaneously in a business. Therefore, small business owners must be able to think quickly but respond professionally and responsibly within safety standards (Dubrin, 2015). The safety of employees is the responsibility of the small business owner (Dubrin, 2015). It is a federal law that employees work in a safe environment without any race, gender, or abuse (Dubrin, 2015). It is the business owner's responsibility to ensure federal regulations are adhered to by staff. In small organizations, Dubrin (2015) posited it is the responsibility of managers to monitor the well-being of each employee, which is often complicated. The task of caring for others can many times be stressful. Managers must monitor each employee in a small establishment. Dubrin (2015) expressed the need for a small organization to create a safe environment that is free from abuse and discrimination. To decrease discrimination and safety violations, managers must implement federal policies in the work environment. The key to a successful business is the manager's ability to act creative and create ways that will foster a highly motivated environment (Hyytinen et al., 2015).

In comparison, Bolman and Deal (2015) expressed how creativity increases employees' morale in the workplace. A small business owner may increase their success by incorporating the recruitment theory in the daily routine during the hiring process. Owners must create an environment that fosters a positive diversified climate to promote internal and external attractiveness (Lambert, 2015).

\section{Research Method and Design}

\section{Research Method}

I used a qualitative research method for this study. Researchers use the qualitative method to understand a phenomenon, and this method is an informal means of thought that researchers can use to increase efforts by explaining the behavior of humans (Longfield et al., 2016). A qualitative research study consists of experientially descriptive data that researchers obtain through direct contact with participants to examine events, record data, explain why and how a phenomenon happened, and to verify how the event affected people and organizations (Clark \& Clark, 2016).

\section{Research Design}

Hyett, Kenny, and Dickson-Swift (2014) defined a case study as a method to explore single or multiple cases to answer research questions. I used a multiple 
case study design for this study because the goal was to collect information from multiple participants. Thomas (2015) noted that a case study is relevant when the researcher incorporates comprehensive methods by using several data collection processes, techniques, and analytical approaches to focus on how and why questions to understand a phenomenon. Researchers use a case study to explore different circumstances to gain perspectives and obtain an overall balance of a phenomenon. I used a case study design to explore the recruitment strategies used by small business owners who employ military veterans.

I intended to interview multiple participants based on interview questions and to explore multiple cases. Researchers use a multiple case design to develop ideas collected from participants' responses to open-ended interview questions and give an idea of how and why the organization operates (Yin, 2016). To reach data saturation, I asked questions during the interview until no new data or themes emerged. According to Saunders et al. (2018), data saturation occurs when participants have no further information to share. I allowed participants to review a summary of the information they discussed with me during and after the interview to affirm accuracy or to add additional information.

\section{Population and Sampling}

The population included three small business owners in the southeastern area who have implemented successful strategies in recruiting, hiring, and retaining military veterans. The justification for using three participants is because this number is enough for both collecting data and achieving data saturation for a qualitative multiple case study. According to Korstjens and Moser (2018), the use of three participants aligns with a purposeful sample and gives access to the resources needed to conduct the study. To answer the research question in this study, I collected data through interviews with three small business owners in the southeastern area with best practices in recruiting, hiring, and retaining military veterans. The three small business owners were from three different industries includes the information technology, job placement services and veteran assistant services. Yin (2016) described a multiple case study as seldom having a purposeful sample, and participants should make use of limited participants or resources (Korstjens \& Moser, 2018).

In comparison, researchers use a purposeful sample to obtain in-depth information from participants to gain knowledge on a specific topic to identify cases relevant to the phenomenon (Palinkas et al., 2015). I used a purposeful sample to gather information from participants at three different locations in southeastern Virginia. Palinkas et al. (2015) defined purposeful sampling as a method for accessing information-rich cases to gather related data on a research topic of interest.

Rubin and Rubin (2012) described data saturation as a combination of data that are compared and identified similarity in patterns among each other. Malterud, Siersma, and Guassora (2016) explained that data saturation is a sample 
size element in a qualitative research study, which often increases within smaller groups. Malterud et al. (2016) expressed the high significance of data saturation with small number groups. I reached data saturation when I interviewed a sample size of three organizations. I conducted face-to-face interviews in a quiet and relaxed location that was practicable for the participants. In this study, I reached data saturation through the interviews of the three chosen participants. As indicated by Morse (2015), one method for acquiring additional participants is asking those contributing to the study for colleague recommendations.

\section{Data Collection Instrument}

In a qualitative research study, the researcher is the primary data collection instrument (Yin, 2016). The researcher must not separate themselves from the research, but rather acknowledge their part in the research process (Fusch \& Ness, 2015). I conducted all primary data collection in this study. I attempted to recognize any bias to limit any inauthenticity in the findings. The researcher must interpret a phenomenon (Fusch \& Ness, 2015). For this study, I conducted semistructured face-to-face interviews, analyze archived data, and conduct observations. To ensure dependability, as recommended by Yin (2018), I followed an interview protocol. I used an interview protocol during the interviews to conduct open-ended interviews as a method of data collection. The use of open-ended interviews provides researchers a way to understand the participants and to see their personal views, interpretations, and opinions (Silverman, 2017).

Rohrer, Brümmer, Schmukle, Goebel, and Wagner (2017) indicated that researchers use open-ended questions to collect pertinent data that is possibly unobtainable using closed-end questions. As a part of the interview protocol, I have listed the open-ended interview questions I asked participants. Once I asked the participants the open-ended questions, I paraphrased their responses and shared them with the participant to ensure accurate interpretation.

I was the data collection instrument that annotated responses during the interviews from the three participants. According to Cope (2014), the researcher usually collects the data and acts as the data instrument. When acting as the instrument, the researcher interviews participants, collect data, and shares findings (Yin, 2016). A researcher collects data from a variety of sources as a data collection instrument (Yeasmin \& Rahman, 2014).

I used reliability and validity as a data collection instrument by using member checking. Researchers use member checking to ensure that participants' feedback will validate and enhance the credibility, accuracy, and transferability of participants' responses (Malave, Diggs, \& Sampayo, 2019). I conducted member checking by synthesizing each question and response, and asking probing questions after the participant responded to the question. Reliability refers to consistency in research and means that the results are both dependable and replicable (Zohrabi, 2013). Reliability will ensure consistency when interviewing participants. Researchers must conclude with similar results from the interviews, to maintain and ensure data is reliable (Zohrabi, 2013). Validity in research in- 
cludes creditability and trustworthiness for both the researcher and the participant. Zohrabi (2013) explained validity as accurate research that proves its claim.

\section{Data Collection Technique}

I used semistructured interviews during the interviews. Researchers can obtain data in several ways in a case study (Yin, 2016). Researchers most commonly use semistructured interviews and document review as the data collection technique in a qualitative case study (Cleland, 2017). Semistructured interviews allow participants to answer open-ended questions and will enable the researcher to gather insightful data (Grossoehme, 2014). This research study involved three small business owners. The interviews were semistructured and recorded. All interview questions were face-to-face and open-ended. All interviews took place after IRB approval. I researched historical data for each organization, as both face-to-face and historical data have advantages and disadvantages.

The advantage of a face-to-face interview is the ability to establish rapport and gestures, and the researcher can see the actual person they are interviewing. Open-ended questions during the interview allowed the participant to share learned experiences in a quiet setting at the best time that fit participants' schedules. The disadvantage of face-to-face interviews included the time it takes to sit and share successful strategies. To overcome the disadvantages and challenges, I conducted a time that best fitted the participants and in a setting where they felt comfortable. I used QSR NVivo Version 11 software to organize data that was collected. The disadvantage in reviewing documents included dated information, bias behaviors, and unavailability of resources (Booth, 2016). Marshall and Rossman (2016) explained ways member checking can boost a qualitative study constancy. I used member checking to analyze participants' relayed data. I used member checking to enhance the reliability and validity of the interview results. To complete the member checking process, I scheduled a second meeting with participants and reviewed the responses with them and made any corrections that were needed. Through this method, I ensured an accurate understanding of each participant's response and solidified the data, to include data saturation.

\section{Data Organization Techniques}

Alsaawi (2014) discussed the importance of keeping data organized during qualitative research that consists of data and transcribed interviews. During this research study, I took many steps to organize data techniques. I used a case study database, which Yazan (2015) stated, is a formal method of assembling evidence used in research to track and gather information in this multiple case study. Researchers use the case study database to organize annotated bibliographies, historical documents, future interviews, and transcripts. I used my personal computer to download and translate electronic audio files to protect and preserve research data. All handwritten information from the interview was transferred to electronic files on my personal computer. I used the NVivo 11 software to transcribe data to help sort information, store, and code interview 
information.

\section{Date Analysis}

Data analysis is a system used to arrange, evaluate, consolidate, and review all research from the data collection. Data analysis is time consuming and is used by qualitative researchers to improve research study findings and quality (Stuckey, 2015). Rowley (2014) identified the critical components of data analysis as 1) inspect and organize, 2) data familiarization, 3) classify data, 4) data coding and interpreting, and 5) presenting and writing data. I conducted interviews after I received IRB approval. Next, I interviewed the participants.

Yin (2015) explained the data analysis tool triangulation as the use of at least two sources to validate research in a study. Researchers use methodological triangulation to increase validity in qualitative research through interviews, observation, surveys, and documents to support research findings (Denzin \& Giardina, 2016; Heale \& Forbes, 2013). Morse (2015) expressed the necessity of using a methodological triangulation in the data analysis process to triangulate data. Two types of triangulation research typically used are methodology or data triangulation. I used data triangulation to interview multiple sources and examined archived records and documents. I organized all information recorded from every interview, ensured the data was adequately coded, analyzed, synthesized, and evaluated to reach data triangulation. I used data triangulation to assist me with identifying themes. I coded data manually and entered data in the NVivo software system to collect themes from the interview data. I used the NVivo software to analyze, organize, and code the data from interviews until themes emerge. To reach data saturation, I asked probing questions after each question until no new data or themes emerged. According to Saunders et al. (2018), data saturation occurs when no new data emerge from participants. I reviewed the responses and summary with each participant on the information they shared with me during the interview to affirm accuracy.

\section{Reliability and Validity}

Reliability warrants the quality and increases the reliability of findings in a qualitative research case study to prevent errors (Foley \& O'Connor, 2013). According to Taylor (2013), researchers measure reliability as the quality and efficiency of the findings from the research study. Fusch and Ness (2015) recommended that researchers use member checking to solidify the dependability and reliability of findings. Member checking in a qualitative research study increases reliability and validity (Foley \& O'Connor, 2013).

In comparison, Yin (2015) recommended that researchers use member checking to confirm findings and clarification of data. I used member checking by relying on participants to clarify data or validate the reliability of the information given. I used member checking to add objectivity, reliability, and dependability by allowing participants to review my interpretation of their responses ensuring accuracy of the data. 
The bases of validity of research are to provide credibility and trustworthiness, dependability, and transferability of the findings from the study (Cope, 2014). Morse (2015) stated that member checking is a method used to validate data. Researchers establish credibility through observation, member checking, and triangulation with research to ensure the accuracy of research data (Marshall \& Rossman, 2016). I ensured credibility by using triangulation and member checking of data from interviews with participants. I recorded all interviews conducted. To verify accuracy, I met with participants to review a summary of their transcript that I recorded during their interview.

Anney (2014) described confirmability as an external investigation of a research study. Researchers use confirmability to interpret the findings from a participants' response without interjecting the researcher's thoughts and potential bias (Korstjens \& Moser, 2018). I thoroughly explored the notes taken from participants prior and after each interview for confirmability. When a researcher reaches a point where there is no additional or new information or related themes emerging, data saturation has occurred (Constantinou, Georgious, \& Perdikogianni, 2017). To reach data saturation, I examined and coded each participant's responses multiple times.

Dependability is the consistency of data and findings (Anney, 2014). Having consistent evidence is an example of data triangulation (Noble \& Smith, 2015). Dependability is repetitiveness in the findings so that all findings are consistent (Sutton \& Austin, 2015). To ensure dependability, as recommended by Yin (2018), I followed an interview protocol.

Cope (2014) explained that the transferability of research findings consists of multiple groups or situations during a study that other researchers may use. Detailed reports from the interviews will reveal if the appropriate information is transferable (Noble \& Smith, 2015). I recruited participants in managerial positions like others in managerial positions, which added to transferability. Transferability is the external verification of research (Daniel, 2018).

Researchers achieve data saturation when they have analyzed all the data, and no new themes emerge. According to Constantinou et al. (2017), data saturation happens when the research has no new data or related themes to describe the phenomena of the study. I checked for data saturation during the interview process by examining, analyzing, and coding data received from the participants.

\section{Findings}

In this study, I conducted semistructured interviews to gain an understanding of strategies leaders in small businesses use to recruit, hire, and retain qualified military veterans. The research question for this study was: What strategies do small business leaders use to recruit, hire, and retain military veterans? I applied the recruitment framework to investigate the strategies small businesses use to employ transitioning military veterans. I collected data to answer the research question by conducting interviews with participants and reviewing company 
documents such as hiring assessments. I conducted semistructured interviews with three participants from three different small businesses; participants will be identified as P1, P2, and P3. I conducted interviews in a quiet and confidential area where the participants felt comfortable and relaxed.

After collecting data, analyzing interviews, and coding data, four themes emerged: 1) social media advertisement, 2) local networking with military facilities, 3) workshop and job description, and 4) resume review and effective communication. I compared the data collection relationship between recruiting, hiring, retaining military veterans, and aligned the themes using the conceptual framework study of recruitment theory (Dunnette, 1976; Farndale et al., 2015). I describe how the findings confirm, disconfirm, or extend knowledge aligned with the literature review. I gained knowledge on recruitment changes, needs while embracing the strengths of qualified veterans, and how each relates to the conceptual framework used in my study. I have listed the four themes from the in-depth examination in my study in Table 1.

Theme 1: Social Media Advertisement

The first theme identified was social media advertisements from all participants (P1, P2, and P3). Erdoğmuş and Çiçek (2012) discussed social media as a platform that has a positive effect when properly used. Social media marketing received attention from academia and practitioners in the new era (Erdoğmuş \& Çiçek, 2012). The participants identified social media advertising as a vital tool in recruiting veterans for their organizations. Zang and Ye (2015) described Internet recruiting as one of the most prominent methods to advertise job positions. P1 stated that,

They depend heavily on social media for a high number of qualified veterans. They use sources like Indeed, LinkedIn, and others to reach the masses of veterans, and the great thing about that is, it gives us business intelligence in terms of veterans. So usually, when the veterans put their application in on Indeed or LinkedIn websites, they have already identified themselves as veterans, which is the focal point organizations look for when they are going to employ for open positions.

According to Zang and Ye (2015), a powerful method to use as an external source is Internet recruiting, which is a prominent way to advertise jobs. P3 stated, "that they always look at the veteran's preferences." In comparison, P1

Table 1. Summary of main themes.

\begin{tabular}{cc}
\hline Themes & Occurrences \\
\hline Social media advertisement & P1, P2, P3 \\
Local networking with military families & $\mathrm{P} 1, \mathrm{P} 2$ \\
Workshops and job description & $\mathrm{P} 1, \mathrm{P} 2, \mathrm{P} 3$ \\
Resume review and effective communication & $\mathrm{P} 1, \mathrm{P} 2, \mathrm{P} 3$ \\
\hline
\end{tabular}


stated, "that they review veteran's military background." Al Ariss, Cascio, and Paauwe (2014) expressed the challenges with recruitment in small businesses. Organizations experience significant challenges with recruiting, hiring, and retaining military veterans (Schiemann, Seibert, \& Blankenship, 2018).

P2 added, "Our recruitment department heavily uses social media to capture military veterans that are transitioning, in transit, or recently separated from the military to identify potential candidates to fill our vacant positions." The Veterans Administration released a policy in 2011 that encouraged the use of social media (Brewin, 2011). The change in the Veterans Administration policy filtered through to veterans seeking employment and encouraged veterans to search the Internet for job vacancies. P2 shared, "LinkedIn has been a vital and significant social media tool that identifies the pool of population their organizations looked for, which is the military veteran population." Campion, Ployhart, and Campion (2017) stated that recruitment is a process organizations use to fill positions, and organizations may advertise through several methods to reach qualified applicants. According to Teo et al. (2018), a reasonable assumption is to see military veterans use social media to reach a variety of U.S. companies looking for qualified applicants. Gërxhani and Koster (2015) stated that small business owners could use external recruiting mechanisms to identify potential candidates who are competitive and have the qualifications to fill available positions, which aligns with this theme.

P3 shared that they "have an excellent outcome by using social media." Social media minimizes their recruiting department's worktime because sites like LinkedIn and Indeed identify the pool of potential military veterans they are seeking. P3 also posited "that $75 \%$ of their employees are military veterans that were identified through LinkedIn or Indeed." Hayati (2019) shared that job advertisement is the primary recruitment tool to find qualified applicants searching for employment, which aligns this theme to the recruitment conceptual framework theory. P3 expressed the "high ratio of veterans that are vetted and hired through social media has allowed the business to flourish and save financially." Advertisement is necessary for businesses and social media allows organizations to reach the masses (Campion et al., 2017). Villeda and McCamey (2019) stated that social media sites are used to recruit and select qualified candidates and organizations benefit by reducing cost, decrease time recruiters spend on each employee, reaching the masses of potentially qualified applicants, and the ability to minimize passive applicants. Therefore, the job descriptions and veterans transitioning workshops align with the literature review and recruitment theory. This theme also confirmed the findings of Muscalu (2015), who asserted that business owners had a larger pool of candidates to pull from external recruitment sources, resulting in a pool of qualified applicants from around the world that best fit the advertised job opening. Table 2 shows a brief description and aggressiveness of each participant's recruitment involvement with social media advertisements.

Theme 2: Local Networking with Military Facilities 
Table 2. Social media advertisement analysis.

\begin{tabular}{cccc}
\hline Description & P1 & P2 & P3 \\
\hline Use social media to find applicants & $100 \%$ & $100 \%$ & $100 \%$ \\
Use competitive analysis to get resumes' & $100 \%$ & $100 \%$ & $100 \%$ \\
Use social media to advertise vacant positions & $100 \%$ & $100 \%$ & $100 \%$ \\
See an upward trend with veterans using social media & $100 \%$ & $100 \%$ & $100 \%$ \\
\hline
\end{tabular}

P2 shared "the effectiveness of networking locally and with military facilities, to get the maximum flash to bang (short timeframe) with employing qualified military veterans for open positions." P1 shared, "The key barrier is access to military facilities and influence as a veteran." P1 has access to the military bases and military facilities, and prior service gives them familiarity with service members and military locations. P1 continued, "Other companies do not have access, and the process they go through to get that access on military posts to attend job fairs and other transitioning events becomes more of a challenge." All three participants use TAP to filter qualified veterans. External recruitment sources are valuable resources that can assist in providing quality candidates (Muscalu, 2015).

P2 stated, "Local networking with military facilities is all about being exposed because there are so many veterans transitioning-that is, it is almost like a tsunami of information, especially when we do not have a military background." Zoli, Maury and Fay (2015) explained the leading gap in military veterans' transition from the armed services is a lack of collaboration, coordination, and collective purpose. Networking with local facilities' program coordinators has allowed P2's company to produce quality workers who are all prior military service personnel. P2 explained, "The hiring managers look directly into those programs that provide military personnel as they transition from the military." P2 stated, "There is a significant military presence here." The organization makes sure they are engaged and have a presence with local military facilities and initiatives on each military base or other supporting organizations that have job fairs for transitioning veterans. P2 shared, "We look at what best aligns with our company's strategy." The company visits military bases monthly to attend job fairs. This company has direct access to job fairs and events on military facilities.

Participants discussed the return on investment of using local network strategies with military facilities. All participants identified local networking as a strategy that enhances business growth and sustainability. Building relationships with local military facilities increases the organization's structure and learning abilities. Each participant fostered a relationship with local military facilities to identify qualified military veterans who fit open positions in their organization. In alignment with this theme, Farndale et al. (2015) stated that organizations that are well-diversified on recruitment and can embrace qualified veterans' skill sets might increase the overall impact of the business. Table 3 displays the results of 
Table 3. Local networking with military facilities analysis.

\begin{tabular}{cccc}
\hline Description & P1 & P2 & P3 \\
\hline Use social media to find applicants & $100 \%$ & $100 \%$ & $0 \%$ \\
Use competitive analysis to get resumes & $100 \%$ & $100 \%$ & $0 \%$ \\
Use social media to advertise vacant positions & $100 \%$ & $100 \%$ & $0 \%$ \\
See an upward trend with veterans using social media & $100 \%$ & $100 \%$ & $0 \%$ \\
\hline
\end{tabular}

each participant using local networking strategies at military facilities to interact with transitioning veterans.

\section{Theme 3: Workshop and Job Description}

Participants shared information on how they attend workshops to mirror their job descriptions. P1stated, "They attend multiple veterans' workshops or events where veterans will be present because the workshops are veteran focused." So, that is the first thing compared to other companies that may not go to those events. P1 shared that "other companies tend not to attend workshops because they do not see the need." Keeling, Kintzle, and Castro (2018) expressed the importance of veteran's integration and how military personnel should receive transitioning into corporate America during the TAP process by veterans who have transitioned. The participant makes attending the event our priority because that is how they get contact with veterans, and because it is a broad base or military presence, the military work very well for them. Lambert (2015) emphasized that business owners that invested in developing a robust recruitment strategy by openly embracing multicultural and diversity would attract educated, talented, and knowledgeable applicants in a broad spectrum. Secondly, participants contributed in the Skill Bridge Program, which is spearheaded by The Chamber Hiring Vets Now. The Chamber Hiring Vets Now allows veterans that are within 1 to 6 months from transitioning to do an internship with a commercial company. P1 stated, "Right now, the veterans have to go through Prance, which is the most popular business for these veterans, especially those veterans with an Information Technology (IT) background and cybersecurity that can do a fellowship at the participant's company." Currently, P1's company has five fellows, and the PRANCE program enhances skill traits that align with the organization of the P1 job description.

Small business businesses hiring managers with networking skills who are social media savvy are great assets to organizations that are looking to employ experienced military veterans transitioning from the armed forces. All participants expressed the need and importance of networking with local military facilities and using social media as a recruiting tool. All participants shared that they depend heavily on social media to recruit for their positions. Participants reinforced Ahmed, Ramachandra, and Jadav (2014) discussion on taking advantage of external recruitment resources, which aligns with the conceptual framework in the literature review. Zang and Ye (2015) explained how external recruitment 
is one of the most effective ways for organizations to advertise open jobs.

Participants confirmed workshops and job descriptions as a bridge to gain access to a larger military service group. Dunnette described the recruitment theory as finding an experience applicant that is the perfect candidate for the position. P1, P2, and P3 shared that their organizations provided detailed job description when attending workshops, which has been a tremendous help with placing qualified candidates in the right positions. This theme aligns with Ramhit (2019) recruitment theory and literature review that job descriptions are vital to getting the right employees who will be successful and ensure employees are familiar with their daily job duties.

Holzer (2017) discussed ways organizations could approach recruitment through workshop training and technical educations; therefore, this theme aligns with recruitment theory. P1, P2, and P3 shared their organizations benefit from attending workshops, presenting job descriptions during the presentation, and advertising available job descriptions on social media. In alignment with this theme, Ekwoaba et al. (2015) indicated that the recruitment stage is given potential employees an introduction to open positions, position descriptions, and required qualifications.

They depend heavily on social media for a high number of qualified veterans. They use sources like Indeed, LinkedIn, and others to reach the masses of veterans, and the great thing about that is, it gives us business intelligence in terms of veterans. So usually, when the veterans put their application in on Indeed or LinkedIn websites, they have already identified themselves as veterans, which is the focal point organizations look for when they are going to employ for open positions.

P2 stated, "They start transitioning anywhere from 1 to 6 months out, and not only does that help with recruiting and narrowing down the job description they are eligible for, it helps us to be able to demonstrate the services and other future service members caliber, quality, and the experience that they get from working with a business like ours."

According to P2, "TAPS makes the transition phase much easier for their organization during the workshops by identifying qualified veterans by job description." Carless and Wintle (2007) stated that during the recruiting process it is crucial for businesses to have job descriptions when adverting jobs and during the interview so applicants know what the job entails, which aligns with the literature review. Kanagavalli, Seethalakshmi, and Sowdamini (2019) posited that organizations that adopted the latest recruiting process such as workshops have been successful in finding the best candidate for the organization, which further align this theme. If a veteran is applying for a job in IT and they have been an IT technician in the Army, Navy, or Air Force, their competencies are tested based on their certification, which goes back to our job description. Military veteran's skill set, and their specific jobs, are identified by Military Occupational Specialty (MOS), which is converted to civilian organizations job description. Those same 
credentials that veterans possess through the Department of Defense are the same at our business.

P3 stated, "they would assist veterans with increasing professional development, networking, sponsorship, and mentorship to better align the veteran to the job position." Boudreau and Rynes (1985) posited that recruitment theory could identify gaps and equip hiring managers with knowledge of what qualified employment veterans are seeking. The TAP program has assisted with making sure transitioning veteran's qualifications meet the organization's job description. Harrell and Berglass (2012) discussed the importance of workshops and job fairs by saying, the two help bridge gaps between employers and transitioning veterans. The findings identified results that indicate advertising job vacancies with a detailed description is an effective strategy for attracting qualified veterans (Dunlap, 2014). The participant found it useful to a job description to seek the best candidates. Farndale et al. (2015) stated that the constructs of recruitment theory would help organizations understand recruitment changes while embracing the power that qualified veterans possess that may increase business revenues. Table 4 includes responses from participants that relate to the workshop and job description.

\section{Theme 4 Resume' Review and Effective Communication}

Each small business owner reviews resumes' and places qualified applicants on an order of merit list (OML) to determine the ranking of a qualified applicant. P1, P2, and P3 shared that they were highly knowledgeable on reading veteran's resumes and how to convert military skills to civilians' job openings. Dunnette (1976) posited that the recruitment theory focuses on systemic approaches of leaders to identify qualified workers that fit the organization's needs. Organizations prepare themselves with the best business practice to successfully hire veterans by making sure staff get additional communication training to communicate better and build trust with military veterans (Keeling et al., 2018). To further align this theme with the literature review, Kanagavalli et al. (2019) asserted that through effective communication with applicants throughout the world,

Table 4. Theme: workshop and job description.

\begin{tabular}{ll} 
Participant & \multicolumn{1}{c}{ Response } \\
P1 & $\begin{array}{l}\text { We face challenges filling positions, and we have to make sure job title and } \\
\text { description aligns with each other. The organization wants to make sure we advertise } \\
\text { all that the position entails getting a quality product candidate. }\end{array}$ \\
& By advertising the job description with in-depth detail, it allows us to get a candidate \\
that can over-perform in the position advertised. Attending the workshop has been a & success for our company with getting quality military veterans that know what they \\
are doing and are eager to be a part of our team. & \\
& We can get anyone to fill our positions, but by attending workshops at local military \\
facilities and having a detailed job description available have been rewarding. This \\
process has filled over $85 \%$ of our positions that were available with quality military \\
veterans.
\end{tabular}


organizations could find the right candidate for available positions. P1 stated that by his organization's competency in understanding the military veteran's resume, they had been successful in identifying the right applicant that fits all their open position. This theme aligns with Bolman and Deal (2015) recruitment theory statement that recruiters must find the right candidate that fits the criteria of an organization.

All participants had a similar response to how they maintain a high retention rate with veterans because of effective communication. P1, P2, and P3 stated that military veterans they hired had been loyal and motivated employees. The results revealed that the organization's close relationship with veterans played an essential part in retention. P1 stated that by effectively communicating with their veteran employees, the employee quickly realized they work for military-friendly companies, and that type of communication is what keeps the retention rate high. Participants responded on how effective communication has a high employee retention rate.

The organizations expressed by them being able to communicate with personnel once hired effectively have been a great asset to increased retention rates. To further align this theme, P1 shared a variety of ways an organization could be successful in recruiting military veterans. P1 expressed that their strategy consisted of making sure their employees understand the use of their benefits. The company found out that most of the veterans they employed were not aware of their available benefits. The homeowners and business loan benefits were two significant benefits veterans did not know about, and by P1 exposing and communicating the information to veterans, was able to retain several employees. P2 posited that through effective communication with their employees, they have been able to increase the retention rate by $42 \%$. The organization invests in their veterans and uses effective communication by providing monthly and quarterly training and educational service. P3 organization make sure their veterans are committed to long-term employment once exiting the service by providing performance goals, incentives, support systems, sponsorships, and mentorship that is tied into veterans achieving quarterly goals. The open communication has allowed veterans to reciprocate and effectively communicate with their employer. Organizations that invest in their employees tend to see the business thrive (Lorinkova, Peaesall, \& Sims, 2013).

P3 stated, "that there are so many entitlements veterans are entitled to, and they do not know, just based on where they are at during that time in their lives." The organizations shared three to four years later benefits such as the veteran's hospital care is available, and their employees did not realize they were eligible because they were too young and did not need the services. P3 shared, "that veterans who have service-connected disabilities are educated by P3 human resource staff on their entitlements, which is a result of effective communication between $\mathrm{P} 3$ and the veteran." $\mathrm{P} 3$ retained veterans because the veterans realize the company is user-friendly, have a direct focus on veterans, and they can get 
information veterans may not be able to get from external sources. There are several executives at all three participant's locations who were prior service members and were able to communicate with employees and external sources to meet the veteran's needs. A successful organization creates positive recruitment strategies to minimize high turnovers (Sutanto \& Kurniawan, 2016), further aligning this theme

The findings in this study correlated with existing literature and aligned with the recruitment theory. Participants shared comparison in the themes could increase small businesses hiring strategies with military veterans. Participants shared that they conduct monthly training with staff on effective communication strategies to communicate with veterans. Lee et al. (2019) described effective communication as the ability to enhance employee's knowledge, skills, and to effectively perform daily tasks in a working environment, which aligned with Dunnette's recruitment theory.

\section{Application to Professional Practices}

The results of this study could be beneficial to current and future small businesses hiring managers by learning strategies they can use to improve daily operational practices with military veterans. The results of this study could improve small business productivity and performance. This study is of value to the practice of business because the findings and recommendations may improve strategies for operational plans when hiring qualified veterans. Four themes emerged during this study: 1) social media advertisement, 2) local networking with military facilities, 3) workshop and job description, and 4) resume' review and effective communication. Small business owners in the local area could benefit from this study as a recruitment tool, to implement strategies in their organization that will align qualified military veterans to positions that the business has available. Dunnette (1976) identified three constructs of recruitment theory, which are 1) organizations need to find skilled workers, 2) identifying qualified applicants, and 3) hiring the right person. Therefore, organizations should embrace recruitment changes, which could increase the overall company's revenues (Farndale et al., 2015). The findings in this study could increase the hiring manager's hiring, recruitment, and retention awareness with military veterans.

Additionally, this study could increase small businesses recruiting awareness and reduce businesses' failure when hiring, recruiting, and retaining military veterans in the state of Virginia. The findings from this study could contribute to increased awareness and collaboration of local military facilities coordinators and small businesses in southeastern Virginia. The coordinators in the area could identify transitioning veterans earlier in the process, aligning qualified veterans with the best job. Small businesses in the area may be motivated to build working relationships with military facilities to ensure a smoother recruitment process and have an effective networking process. Klettner, Clarke, and Boersma (2013) expressed the importance of small business owners to im- 
plement strategies that reduce business failure.

\section{Implications for Social Change}

The findings from this study could help improve small business owner's recruitment strategies and understanding of the military veterans transitioning process. Hiring managers could apply the findings from this study to implement and improve recruitment strategies when hiring military veterans, which could improve the organization's production. The implications of positive social change from this study could reduce recruitment failures and strengthen the hiring process. The social change from this study could impact a small business by allowing hiring managers to become knowledgeable about the military transitioning process. In addition, hiring manager could identify qualified military veterans, and methods to retain their military veteran's employees, which will help sustain small beyond 5 years.

Implications for social change include increasing the recruiting and retention population. If a small business adopts strategies based on the findings from this study, the business could potentially benefit through sustainability and increased profits. Therefore, the local community's unemployment rate may decrease, resulting in stabilizing the local economy. The results of this study could help fill gaps in the literature on what strategies small businesses use for hiring, recruiting, and retaining military veterans in the southeastern Virginia area.

\section{Recommendations for Further Action}

The purpose of this qualitative multiple case study was to explore the strategies used by leaders of small businesses to recruit, hire, and retain qualified veterans. The specific business problem is that some business leaders in small businesses lack strategies to recruit, hire, and retain qualified military veterans. Based on the findings in this research study, I recommend the following actions that may enhance small business recruitment strategies. Small business hiring managers should gain knowledge on four themes to support the recruitment of veterans: 1) social media advertisement, 2) local networking with military facilities, 3) workshop and job description, and 4) resume' review and effective communication.

Hiring managers should use social media advertisement to seek qualified candidates. The use of social media advertisement will also ensure that the job vacancies reach the masses of the transitioning veteran's populations, and to obtain the best candidate suitable for the open jobs. Secondly, organizations should maximize their networking by collaborating with local military facilities, attend workshops and other events that may be available. Thirdly, I would recommend open communications with hiring managers and candidates during the resume' review and as an employee. These open communications create and foster a positive work environment that enhances the company's growth.

The findings from this research are relevant to a small business owner's ability to survive in a competitive economy, which is essential to business sustainability. 
If small business hiring managers are knowledgeable about the hiring process of military veterans, their organization could potentially sustain in a competitive economy. I recommend that small business hiring managers use this study to improve identified strategies used to hire, recruit, and retain military veterans.

\section{Recommendations for Further Research}

I conducted a multiple qualitative case study to explore the strategies used by leaders of small businesses to recruit, hire, and retain qualified veterans. The research population consisted of three businesses in the southeastern Virginia area. The expectations were that findings from this study would fill gaps in the previous recruit of military veteran's literature. Also, to promote a positive social change in areas that are so rich with military populations. Future research study could address more participants in a broader area besides two cities in southeastern Virginia. Future research could also concentrate on larger companies. I had enough participants to reach data saturation, but additional participants could be used to gather a plethora of emerging themes.

\section{Conclusion}

The purpose of this qualitative multiple case study was to explore small business leaders' strategies for recruiting veterans. The conceptual framework that aligned with this research study was the recruitment theory. Four themes emerged from the findings in this study. The themes were 1) social media advertisement, 2) local networking with military facilities, 3) workshop and job description, and 4) resume' review and effective communication. The finding of this study included that participants advertised job vacancies through social media, military post advertisements, human resource boards, and small business administration. Each participant agreed that the labor force hiring process consists of competition with other civilian entities. In conclusion, the finding from this study may identify strategies used by businesses to recruit and retain veterans as employees, which could then be used by other organizations interested in employing.

\section{Conflicts of Interest}

The author declares no conflicts of interest regarding the publication of this paper.

\section{References}

Ahmed, A. A., Ramachandra, M. S., \& Jadav, D. (2014). Campus Recruitment \& Its Worth in Information Technology Sector. International Journal in Management and Social Science, 2, 422-444. http://www.ijmr.net.in

Al Ariss, A., Cascio, W. F., \& Paauwe, J. (2014). Talent Management: Current Theories and Future Research Directions. Journal of World Business, 49, 173-179.

https://doi.org/10.1016/j.jwb.2013.11.001 
Alsaawi, A. (2014). A Critical Review of Qualitative Interviews. European Journal of Business and Social Sciences, 3, 149-156. https://doi.org/10.2139/ssrn.2819536

Anney, B. (2014). Ensuring the Quality of the Finds of Qualitative Research: Looking at the Trustworthiness Criteria. Journal of Emerging Trend in Educational Research and the Policy Studies (JETERAPS), 5, 272-281.

Beauchesne, K., \& O’Hair, J. R. (2013) Investing in Vets: Strategies to Help Returning Gulf War Vets Enter the Civilian Workforce Successfully. Social Work in Mental Health, 11, 434-459. https://doi.org/10.1080/15332985.2013.804021

Ben-Hur, S., Jaworski, B., \& Gray, D. (2015). Aligning Corporate Learning with Strategy. MIT Sloan Management Review, 57, 53-59. http://sloanreview.mit.edu

Blatter, M., Muehlemann, S., \& Schenker, S. (2012). The Costs of Hiring Skilled Workers. European Economic Review, 56, 20-35. https://doi.org/10.1016/j.euroecorev.2011.08.001

Bolman, L. G., \& Deal, T. E. (2015). Think-Or Sink. Lead to Leader, 76, 35-40. https://doi.org/10.1002/lt1.20176

Booth, A. (2016). Searching for Qualitative Research for Inclusion in Systematic Reviews: A Structured Methodological Review. Systematic Reviews, 5, Article No.: 74. https://doi.org/10.1186/s13643-016-0249-x

Boudreau, J. W., \& Rynes, S. L. (1985). Role of Recruitment in Staffing Utility Analysis. Journal of Applied Psychology, 70, 354-366. https://doi.org/10.1037/0021-9010.70.2.354

Brewin, B. (2011). Veterans Affairs Promotes Social-Media Use with New Policy. National Journal. https://www.hanoverresearch.com/media/Veteran-Marketing-Research.pdf

Brown, S. D., \& Lent, R. W. (2013). Career Development and Counseling (2nd ed.). Hoboken, NJ: John Wiley \& Sons.

Campion, M. C., Ployhart, R. E., \& Campion, M. A. (2017). Using Recruitment Source Timing and Diagnosticity to Enhance Applicants' Occupation-Specific Human Capital. Journal of Applied Psychology, 102, 764-781. https://doi.org/10.1037/apl0000190

Carless, S. A., \& Wintle, J. (2007). Applicant Attraction: The Role of Recruitment Function, Work-Life Balance Policies and Career Salience. International Journal of Selection and Assessment, 15, 394-404. https://doi.org/10.1111/j.1468-2389.2007.00398.x

Chungyalpa, W., \& Karishma, T. (2016). Best Practices and Emerging Trends in Recruitment and Selection. Journal of Entrepreneurship \& Organization Management, 5, 173.

Clark, A. M., \& Clark, M. T. (2016). Pokémon Go and Research: Qualitative, Mixed Methods Research, and the Supercomplexity of Interventions. International Journal of Qualitative Methods, 15, 1-3. https://doi.org/10.1177/1609406916667765

Cleland, J. A. (2017). The Qualitative Orientation in Medical Education Research. Korean Journal of Medical Education, 29, 61-71. https://doi.org/10.3946/kjme.2017.53

Constantinou, C. S., Georgious, M., \& Perdikogianni, M. (2017). A Comparative Method for Themes Saturation (CoMeTS) in Qualitative Interviews. Qualitative Research, 17, 571-588. https://doi.org/10.1177/1468794116686650

Cope, D. G. (2014). Methods and Meanings: Credibility and Trustworthiness of Qualitative Research. Oncology Nursing Forum, 41, 89-91.

https://doi.org/10.1188/14.ONF.89-91

Daniel, B. K. (2018). Empirical Verification of the "TACT" Framework for Teaching Rigor in Qualitative Research Methodology. Qualitative Research Journal, 18, 262-275. https://doi.org/10.1108/QRJ-D-17-00012

Denzin, N. K., \& Giardina, M. D. (Eds.) (2016). Qualitative Inquiry and Global Crises. 
Abingdon, UK: Routledge. https://doi.org/10.4324/9781315421612

Dubrin, A. (2015). Leadership: Research Findings, Practice, and Skills. Mason, OH: South-Western/Cengage.

Dunlap, N. (2014). Finding the Right 1. Journal of Property Management, 79, 24-25. https://www.questia.com/magazine/1G1-370458355/finding-the-right-1

Dunnette, M. D. (Ed.) (1976). Handbook of Industrial and Organizational Psychology. Chicago, IL: Rand McNally.

Ekwoaba, J. O., Ikeije, U. U., \& Ufoma, N. (2015). The Impact of Recruitment and Selection Criteria on Organizational Performance. Global Journal of Human Resource Management, 3, 22-33. http://www.eajournals.org

Erdoğmuş, I. E., \& Çiçek, M. (2012). The Impact of Social Media Marketing on Brand Loyalty. Procedia-Social and Behavioral Sciences, 58, 1353-1360. https://doi.org/10.1016/j.sbspro.2012.09.1119

Faberman, R. J., \& Foster, T. (2013). Unemployment among Recent Veterans during the Great Recession. Economic Perspectives, 37, 1-13. https://www.chicagofed.org/publications/economic-perspectives/index

Farndale, E., Biron, M., Briscoe, D. R., \& Raghuram, S. (2015). A Global Perspective on Diversity and Inclusion in Work Organisations. The International Journal of Human Resource Management, 26, 677-687. https://doi.org/10.1080/09585192.2014.991511

Faurer, J., Rogers-Brodersen, A., \& Bailie, P. (2014). Managing the Re-Employment of Military Veterans through the Transition Assistance Program (TAP). Journal of Business \& Economics Research, 12, 55-60. https://doi.org/10.19030/jber.v12i1.8378

Flannery, M. (2016). Explicit Assumptions about Knowing. Oncology Nursing Forum, 43, 245-247. https://doi.org/10.1188/16.ONF.245-247

Foley, D., \& O’Connor, A. J. (2013). Social Capital and Networking Practices of Indigenous Entrepreneurs. Journal of Small Business Management, 51, 276-296. https://doi.org/10.1111/jsbm.12017

Fusch, P. I., \& Ness, L. R. (2015). Are We There Yet? Data Saturation in Qualitative Research. The Qualitative Report, 20, 1408-1416. http://tqr.nova.edu

Gërxhani, K., \& Koster, F. (2015). Making the Right Move. Investigating Employers' Recruitment Strategies. Personnel Review, 44, 781-800.

https://doi.org/10.1108/PR-12-2013-0229

Grossoehme, D. H. (2014). Research Methodology: Overview of Qualitative Research. Journal of Health Care Chaplaincy, 20, 109-122. https://doi.org/10.1080/08854726.2014.925660

Gutiérrez-Broncano, S., Jiménez-Estévez, P., \& del Carmen Zabala-Baños, M. (2017). Behavior of Internal Customer in Family Business: Strategies and Actions for Improving Their Satisfaction. Frontiers in Psychology, 8, 1266-1272. https://doi.org/10.3389/fpsyg.2017.01266

Harrell, M. C., \& Berglass, N. (2012). Employing America's Veterans-Perspectives from Businesses. http://www.benefits.va.gov/vow/docs/employingamericasveterans.pdf

Hayati, N. R. (2019). Building a Conceptual Framework for Recruitment Process. Global Business and Management Research, 11, 242-248. https://ezp.waldenulibrary.org/login?qurl=https $\% 3 \mathrm{~A} \% 2 \mathrm{~F} \% 2 \mathrm{Fsearch}$. proquest.com $\% 2 \mathrm{~F}$ docview\%2F2236126557\%3Faccountid\%3D14872

Heale, R., \& Forbes, D. (2013). Understanding Triangulation in Research. Evidence-Based Nursing, 16, 98. https://doi.org/10.1136/eb-2013-101494 
Holzer, H. J. (2017). The Role of Skills and Jobs in Transforming Communities. Cityscape: A Journal of Policy Development \& Research, 19, 171-190.

https://www.jstor.org

Hyett, N., Kenny, A., \& Dickson-Swift, V. (2014). Methodology or Method? A Critical Review of Qualitative Case Study Reports. International Journal of Qualitative Studies on Health and Well-Being, 9, Article No.: 23606. https://doi.org/10.3402/qhw.v9.23606

Hyytinen, A., Pajarinen, M., \& Rouvinen, P. (2015). Does Innovativeness Reduce Startup Survival Rates? Journal of Business Venturing, 30, 564-581. https://doi.org/10.1016/j.jbusvent.2014.10.001

Jaouen, A., \& Lasch, F. (2015). A new Typology of Micro-Firm Owner-Managers. International Small Business Journal, 33, 397-421. https://doi.org/10.1177/0266242613498789

Kanagavalli, G., Seethalakshmi, R., \& Sowdamini, T. (2019). A Systematic Review of Literature on Recruitment and Selection Process. Humanities \& Social Sciences Reviews, 7, $1-9$.

Keeling, M., Kintzle, S., \& Castro, C. A. (2018). Exploring U.S. Veterans' Post-Service Employment Experiences. Military Psychology, 30, 63-69.

https://doi.org/10.1080/08995605.2017.1420976

Klettner, A., Clarke, T., \& Boersma, M. (2013). The Governance of Corporate Sustainability: Empirical Insights into the Development, Leadership, and Implementation of Responsible Business Strategy. Journal of Business Ethics, 122, 145-165. https://doi.org/10.1007/s10551-013-1750-y

Korstjens, L., \& Moser, A. (2018). Series: Practical Guidance to Qualitative Research. Part 4: Trustworthiness and Publishing. European Journal of General Practice, 24, 120-124. https://doi.org/10.1080/13814788.2017.1375092

Kube, S., Maréchal, M. A., \& Puppe, C. (2013). Do Wage Cuts Damage Work Morale? Evidence from a Natural Field Experiment. Journal of the European Economic Association, 11, 853-870. https://doi.org/10.1111/jeea.12022

Lambert, J. R. (2015). The Impact of Gay-Friendly Recruitment Statements and Due Process Employment on a Firm's Attractiveness as an Employer. Diversity and Inclusion: An International Journal, 34, 510-526. https://doi.org/10.1108/EDI-03-2013-0012

Lee, M. C., Idris, M. A., \& Tuckey, M. (2019). Supervisory Coaching and Performance Feedback as Mediators of the Relationships between Leadership Styles, Work Engagement, and Turnover Intention. Human Resource Development International, 22, 257-282. https://doi.org/10.1080/13678868.2018.1530170

Lewin, S., Glenton, C., Munthe-Kaas, H., Carlsen, B., Colvin, C. J., Gulmezoglu, M., Rashidian, A. (2015). Using Qualitative Evidence in Decision Making for Health and Social Interventions: An Approach to Assess Confidence in Findings from Qualitative Evidence Syntheses (GRADE-CERQual). PLoS Medicine, 12, e1001895.

https://doi.org/10.1371/journal.pmed.1001895

Longfield, K., Moorsmith, R., Peterson, K., Fortin, I., Ayers, J., \& Lupu, O. (2016). Qualitative Research for Social Marketing: One Organization's Journey to Improved Consumer Insight. Qualitative Report, 21, 71-86. https://nsuworks.nova.edu/tqr/vol21/iss1/7/

Lorinkova, N. M., Peaesall, M. J., \& Sims Jr., H. P. (2013). Examining the Differential Longitudinal Performance of Directive versus Empowering Leadership in Teams. Academy of Management Journal, 56, 1372-1395.

https://doi.org/10.5465/amj.2011.0132 
Malave, C. S., Diggs, D., \& Sampayo, E. M. (2019). Spanish-Speaking Caregivers' Experience with an Emergency Department Pediatric Asthma-Care Bundle Quality Initiative. Journal of Racial and Ethnic Health Disparities, 2, 1-8.

Malterud, K., Siersma, V. D., \& Guassora, A. D. (2016). Sample Size in Qualitative Interview Studies: Guided by Information Power. Qualitative Health Research, 26, 1753-1760. https://doi.org/10.1177/1049732315617444

Marshall, C., \& Rossman, G. (2016). Designing Qualitative Research (6th ed.). Thousand Oaks, CA: Sage.

Morse, J. (2015). Critical Analysis of Strategies for Determining Rigor in Qualitative Inquiry. Qualitative Health Research, 25, 1212-1222. https://doi.org/10.1177/1049732315588501

Muscalu, E. (2015). Sources of Human Resources Recruitment Organization. Land Forces Academy Review, 20, 351-359. https://www.armyacademy.ro/reviste/rev3_2015/MUSCALU.pdf

Noble, H., \& Smith, J. (2015). Issues of Validity and Reliability in Qualitative Research. Evidence-Based Nursing, 18, 34-35. https://doi.org/10.1136/eb-2015-102054

Palinkas, L. A., Horwitz, S. M., Green, C. A., Wisdom, J. P., Duan, N., \& Hoagwood, K. (2015). Purposeful Sampling for Qualitative Data Collection and Analysis in Mixed Method Implementation Research. Administration and Policy in Mental Health and Mental Health Services Research, 42, 533-544. https://doi.org/10.1007/s10488-013-0528-y

Ramhit, K. S. (2019). The Impact of Job Description and Career Prospect on Job Satisfaction: A Quantitative Study in Mauritius. SA Journal of Human Resource Management/SA Tydskrif vir Menslikehulpbronbestuur, 17, a1092. https://doi.org/10.4102/sajhrm.v17i0.1092

Rohrer, J. M., Brümmer, M., Schmukle, S., Goebel, J., \& Wagner, G. G. (2017). What Else Are You Worried about?-Integrating Textual Responses into Quantitative Social Science Research. PLOS ONE, 12, e0182156. https://doi.org/10.1371/journal.pone.0182156

Rowley, J. (2014). Designing and Using Research Questionnaires. Management Research Review, 37, 308-330. https://doi.org/10.1108/MRR-02-2013-0027

Rubin, H. J., \& Rubin, I. S. (2012). Qualitative Interviewing: The Art of Hearing Data (3rd ed.). Thousand Oaks, CA: Sage.

Saunders, B., Sim, J., Kingstone, T., Baker, S., Waterfield, J., Bartlam, B., \& Jinks, C. (2018). Saturation in Qualitative Research: Exploring Its Conceptualization and Operationalization. Quality \& Quantity, 52, 1893-1907. https://doi.org/10.1007/s11135-017-0574-8

Schiemann, W. A., Seibert, J. H., \& Blankenship, M. H. (2018). Putting Human Capital Analytics to Work: Predicting and Driving Business Success. Human Resource Management, 57, 795-807. https://doi.org/10.1002/hrm.21843

Silverman, D. (2017). How Was It for You? The Interview Society and the Irresistible Rise of the (Poorly Analyzed) Interview. Qualitative Research, 17, 144-158.

https://doi.org/10.1177/1468794116668231

Stuckey, H. (2015). The Second Step in Data Analysis: Coding Qualitative Research Data. Journal of Social Health and Diabetes, 3, 7-10. https://doi.org/10.4103/2321-0656.140875

Sutanto, E. M., \& Kurniawan, M. (2016). The Impact of Recruitment, Employee Retention and Labor Relations to Employee Performance on Batik Industry in Solo City, In- 
donesia. International Journal of Business and Society, 17, 375-390.

http://www.ijbs.unimas.my/

https://doi.org/10.33736/ijbs.531.2016

Sutton, J., \& Austin, Z. (2015). Qualitative Research: Data Collection, Analysis, and Management. The Canadian Journal of Hospital Pharmacy, 68, 226-231.

https://doi.org/10.4212/cjhp.v68i3.1456

Taylor, M. A. (2013). Travel through Time: The Story of Research on Travel Time Reliability. Transportmetrica B: Transport Dynamics, 1, 174-194. https://doi.org/10.1080/21680566.2013.859107

Teo, A. R., Marsh, H. E., Liebow, S. B. L., Chen, J. I., Forsberg, C. W., Nicolaidis, C., et al. (2018). Help-Seeking on Facebook versus More Traditional Sources of Help: Cross-Sectional Survey of Military Veterans. Journal of Medical Internet Research, 20, e62. https://doi.org/10.2196/jmir.9007

Thomas, S. J. (2015). Exploring Strategies for Retaining Information Technology Professionals: A Case Study (Doctoral Dissertation). Available at ProQuest Dissertations and Theses Database. (UMI No. 3681815)

U.S. Census Bureau (2015). American Community Survey (ACS). https://www.census.gov/programs-surveys/acs

U.S. Department of Defense (2016). Operation and Maintenance Overview Fiscal Year 2016 Budget Estimates.

http://comptroller.defense.gov/Budget-Materials/Budget2016/

U.S. Department of Labor (2017). Bureau of Labor Statistics. https://www.bls.gov/bls/news-release/

U.S. Small Business Administration (SBA) (2014). Small Business Size Standards: Summary of Size Standards by Industry Sector. Washington, DC: SBA. https://www.sba.gov/content/summary-size-standards-industry-sector

U.S. Small Business Administration (SBA) (2017). Small Business Profile: Virginia. Washington, DC: SBA.

https://www.sba.gov/sites/default/files/advocacy/All_States_0.pdf

U.S. Small Business Administration (SBA) (2018). Small Business Profile: Virginia. Washington, DC: SBA.

https://www.sba.gov/sites/default/files/advocacy/2018-Small-Business-Profiles-VA.pdf

Villeda, M., \& McCamey, R. (2019). Use of Social Networking Sites for Recruiting and Selecting in the Hiring Process. International Business Research, 12, 66. https://doi.org/10.5539/ibr.v12n3p66

Yazan, B. (2015). Three Approaches to Case Study Methods in Education: Yin, Merriam, and Stake. The Qualitative Report, 20, 134-152. https://nsuworks.nova.edu/tqr/vol20/iss2/12/

Yeasmin, S., \& Rahman, K. F. (2014). Triangulation Research Method as the Tool of Social Science Research. BUP Journal, 1, 154-163. http://www.bup.edu.bd

Yin, R. K. (2015). Qualitative Research from Start to Finish (2nd ed.). New York: Guilford Press.

Yin, R. K. (2016). Qualitative Research from Start to Finish (2nd ed.). New York: Guilford Press.

Yin, R. K. (2017). Case Study Research: Design and Methods (6th ed.). Thousand Oaks, CA: Sage Publications Inc.

Yin, R. K. (2018). Case Study Research: Design and Methods (6th ed.). Thousand Oaks, 
CA: Sage Publications.

Zang, S., \& Ye, M. (2015). Human Resource Management in the Era of Big Data. Journal of Human Resource and Sustainability Studies, 3, 41-45.

https://doi.org/10.4236/jhrss.2015.31006

Zogas, A. (2017). US Military Veterans' Difficult Transition Back to Civilian Life and the VA's Response. Cost of War, 1-14.

https://watson.brown.edu/costsofwar/papers/2017/us-military-veterans-difficult-transit ions-back-civilian-life-and-va-s-response

Zohrabi, M. (2013). Mixed Method Research: Instruments, Validity, Reliability and Reporting Findings. Theory and Practice in Language Studies, 3, 254-262. https://doi.org/10.4304/tpls.3.2.254-262

Zoli, C., Maury, R., \& Fay, D. (2015). Missing Perspectives: Service Members' Transition from Service to Civilian Life-Data-Driven Research to Enact the Promise of the Post-9/11 GI Bill. Syracuse, NY: Institute for Veterans \& Military Families, Syracuse University. 